\title{
Identification of The Geothermal Heat at Mount lyang-Argopuro Based on a Data Image of Landsat 8 Satellite and a Data Gravity of GGMPIus Satellite
}

\author{
Ega Abi Bahtiar ${ }^{1, a}$, Agus Suprianto ${ }^{1}$ and Supriyadi ${ }^{1}$ \\ ${ }^{1}$ Departement of Physics, Faculty of Mathematics and Natural Sciences, Universitas Jember, \\ Kalimantan Street No. 37, Jember 68121, Indonesia \\ aegaabibahtiar@gmail.com
}

\begin{abstract}
In Indonesia is the lyang-Argopuro Volcano Complex. The Research uses remote sensing methods and gravity methods conducted to study thermal anomalies and subsurface structures using data images of Landsat 8 satellite and a data gravity of GGMplus satellite. Moreover, the study aims to estimate the number of hoisting manifestations of the earth's heat at the compound of the lyang-Argopuro Volcano. Landsat 8 satellite image data is a spectral band (band 1-9) and a thermal band (band 10 and 11). The data was done in radiometric corrections, radiance correction, and reflex corrections, and was thus obtained a value of ground surface temperature (LST). The data was done in radiometric corrections, radiance correction, and reflectance corrections, to get an LST value. Processing data gravity of GGMPlus satellites were with a bouguer correction, terrain corrections up to get a complete bouguer anomaly $(A B L)$ value. Furthermore, the $A B L$ value consisting of regional and local anomalies is separated using an upward continuation filter to obtain local anomaly values. The results obtained from this study are five points of geothermal manifestation locations in the lyang-Argopuro Volcano Complex which are located in the northern, central, southern and eastern parts. Manifestations in the northern, central, and northeastern parts have ground surface temperatures of $24-31{ }^{\circ} \mathrm{C}$. While manifestations in the central and eastern parts have a surface temperature of land $21-31{ }^{\circ} \mathrm{C}$. The high ground temperature values at the five locations were associated with low gravity values ranging from $-20 \mathrm{mGal}$ to $-10 \mathrm{mGal}$. The low gravity value is assumed to have a rock structure with a low-density value. Low-density rock structures have the possibility of an outflow zone causing the soil surface temperature to be relatively high.
\end{abstract}

Keywords: Geothermal, Gravity Anomaly, Thermal Anomaly, Outflow Zone

\section{Introduction}

Indonesia's geographical location is crossed by the pacific's ring of fire. This causes Indonesia have to abundant natural resources, one of which is geothermal. Geothermal potential in Indonesia is quite large, around $40 \%$ of the total potential in the world. Until 2014, the utilization of geothermal potential in Indonesia has only reached $1341 \mathrm{MW}$ or less than $5 \%$ of the available potential [1]. East Java Province has 13 geothermal potential points and one of them is located on Mount lyang-Argopuro. The potential contained in Mount lyang-Argopuro is 295 MW [2,3].

Mount Argopuro is one of the ancient volcanoes located on the island of Java. Mount lyangArgopuro is an active volcano type B, which means that the volcanic activity of this mountain has decreased and is even categorized as resting [4]. The characteristic morphology of the Mount lyang-Argopuro area is surrounded by volcanic hills and the distribution of maar lakes. Lake Maar is a volcanic crater file in the past that is currently in the form of a basin filled with water, as well as sedimentary materials resulting from volcanic eruptions. The majority of the 
lithology types of the Mount lyang-Argopuro geothermal area are pyroclastic rocks, basaltic andesite lava, and tuff [5].

Research conducted by Wulandari et al. stated that the Mount lyang-Argopuro geothermal system consists of a caprock layer, a reservoir rock layer, and a heat source rock layer. Cover rock is in the shallowest layer below the soil surface. The reservoir rock layer is at a depth of 1000-3000 m below the ground surface. The heat source rock layer is a heat-producing rock located at a depth of $3000 \mathrm{~m}$ below the ground surface [5]. The structures that control the geothermal potential of Mount lyang-Argopuro include crater and fault structures. Regionally, Mount lyang-Argopuro is included in the East Java tectonic system with a diagonal shape with a northwest-southeast and northeast-southwest direction [6]. This fault structure on Mount lyangArgopuro allows geothermal manifestations to appear on the ground surface.

Geothermal manifestations that are often seen on the surface are hot springs, hot mud puddles, geysers, fumaroles, warm ground, alteration rocks, and other geothermal manifestations [7]. Geothermal manifestations on Mount lyang-Argopuro are scattered at several points, one of which is the manifestation of hot springs on the northern slopes of Mount Argopuro in the area of Rabunan, Probolinggo. The manifestation of the hot springs arises because there is an outflow zone in the Rabunan area. Other manifestations also found weakly altered andesite outcrops with a whitish color in Kali Putih, Cisentor. Strong alteration zone on Mount Rengganis around the solfatara holes of Mount Rengganis [8]. Manifestations of hot springs are also found on the western slopes located in the Tiris area. The surface temperature of the area was recorded at $46-48{ }^{\circ} \mathrm{C}$ with a $\mathrm{pH}=6$. The existence of this geothermal manifestation is usually connected with the distribution of thermal temperatures that are higher than the temperature of the surrounding environment. The distribution of this temperature anomaly can be observed, one of which is remote sensing technology.

\section{Theoretical Background}

Remote sensing is a technology to obtain information about an object, area, or phenomenon through the analysis of data obtained from a device without directly touching the object, area, or phenomenon [9]. Remote sensing techniques are ideal for use in the initial investigation of geothermal potential. The results of remote sensing data processing can then interpret the earth's surface conditions and the distribution of soil temperature which can be used to identify potential geothermal locations $[10,11]$. One of the remote sensing data used for geothermal identification is Landsat 8.

Landsat 8 has a special advantage compared to the previous generation Landsat, namely more composite RGB constituent bands. In addition, Landsat 8 has bands that make the color of objects more varied, namely $1-9,10$, and 11 . The following Table 1 is a characteristic of the Landsat 8 satellite band.

Table 1. Landsat 8 satellite sensor characteristics

\begin{tabular}{lcc}
\hline \multicolumn{1}{c}{ Band } & $\boldsymbol{\lambda}(\mathbf{n m})$ & Resolusi (m) \\
\hline Band 1-Coastal Aerosol & $0.43-0.451$ & 30 \\
Band 2-Blue & $0.45-0.51$ & 30 \\
Band 3-Green & $0.53-0.59$ & 30
\end{tabular}




\begin{tabular}{lcc}
\hline \multicolumn{1}{c}{ Band } & $\boldsymbol{\lambda}(\mathbf{n m})$ & Resolusi (m) \\
\hline Band 4-Red & $0.64-0.67$ & 30 \\
Band 5-Near Infrared (NIR) & $0.85-0.88$ & 30 \\
Band 6-SWIR 1 & $1.57-1.65$ & 30 \\
Band 7-SWIR 2 & $2.11-2.29$ & 30 \\
Band 8-Panchromatic & $0.50-0.68$ & 15 \\
Band 9-Cirrus & $1.36-1.38$ & 30 \\
Band 10-Thermal Infrared & $10.60-11.19$ & 100 \\
(TIRS) 1 & & \\
Band 11-Thermal Infrared & $11.50-12.51$ & 100 \\
(TIRS) 2 & & \\
\hline
\end{tabular}

Bands 10 and 11 are thermal bands that are used to record thermal activity on the earth's surface, so they are very closely related to monitoring volcanic activity [12]. Bands 1-9 are spectral bands that can be used to calculate the value of the vegetation index on the earth's surface [13].

Normalized Difference Vegetation Index (NDVI) is one of the algorithms used to determine vegetation values by involving satellite imagery [13]. NDVI is generally used to determine the level of vegetation density based on the difference between the maximum absorption in the red wave and the maximum reflectance in the near-infrared wave based on the leaf cell structure [14]. Equation 1 below can be used to calculate the NDVI value.

$N D V I=\frac{\rho_{\text {nir }}-\rho_{\text {red }}}{\rho_{\text {nir }}+\rho_{\text {red }}}$

$\rho_{\text {nir }}=$ the near-infrared band reflectance value

$\rho_{\text {red }}=$ the red band reflectance value

Image data processing using the NDVI algorithm will produce a new image with an NDVI value ranging from negative 1 to positive 1 . A positive NDVI value indicates an object is a vegetation, while a negative NDVI value indicates a non-vegetated object. According to the Departemen Kehutanan (2012), the classification of vegetation density based on the NDVI value consists of five classes, namely unvegetated land, very high green, low green, medium green, and high green [15]. The classification of vegetation density can be seen in Table 2.

Table 2. Vegetation density class [15]

\begin{tabular}{ccc}
\hline Class & NDVI Range Value & Density Level \\
\hline 1 & $-1<\mathrm{NDVI} \leq-0.03$ & Non-vegetated land \\
2 & $-0.03<\mathrm{NDVI} \leq 0.15$ & Very low green \\
3 & $0.15<\mathrm{NDVI} \leq 0.25$ & Low green \\
4 & $0.25<\mathrm{NDVI} \leq 0.35$ & Medium green \\
5 & $0.35<\mathrm{NDVI} \leq 1$ & High greeni \\
\hline
\end{tabular}

According to Sutanto, the Landsat 8 satellite has the best geodetic and geometric accuracy [16]. Characteristics Landsat 8 has a shorter band interval when compared to the previous generation Landsat. Landsat 8 has Thermal Infrared Sensors (TIRS) in bands 10 and 11 which have special characteristics used to record thermal activity on the earth's surface. Bands 10 and 11 are closely related to the monitoring of volcanic activity [12]. Monitoring of volcanic activity can be interpreted from the value of the ground surface temperature. 
Ground surface temperature is one of the parameters of the energy balance on the earth's surface. Based on Wein's Law of Displacement, which states have an object will emit a different electromagnetic wavelength at each emitter temperature. Determination of the temperature of a mass can be known from the measurement of the emission of electromagnetic waves. The electromagnetic wave emission will be captured by the sensor in the form of a digital value [17]. The temperature of the object can be known by a digital value conversion step which aims to eliminate the influence of the atmosphere on the absolute temperature. Temperature conversion needs to be done because the actual object is on the ground while the sensor is in outer space. This conversion in remote sensing techniques is commonly called the Top of Atmosphere (TOA) correction, which is stated in the following equation [18].

$L_{\lambda}=M_{L} Q_{c a l}+A_{L}$

$L_{\lambda} \quad=$ radiance value or reflectance value

$M_{L} \quad=$ the radiance band or spectral band multiplier constant used

$A_{L} \quad=$ the addition constant of the radian band or spectral band used

$Q_{c a l}=$ digital number

The radiance value obtained will then be used to calculate the value of the soil surface temperature. Calculation of the value of the soil surface temperature is obtained from the conversion of the radian value to the Brightness Temperature (BT). According to Kustiyo and Pramono (2005), the BT value can be obtained from the following equation.

$B T=\frac{K_{2}}{\ln \left(\frac{K_{1}}{L_{\lambda}}+1\right)}$

$L_{\lambda} \quad=$ radiance value

$K_{1}$ and $K_{2} \quad=$ thermal conversion constant

$B_{T} \quad=$ brightness temperature value

The BT value obtained is then used to calculate the soil surface temperature using the following equation [18].

$L S T=\frac{B T}{1+\left(\frac{\lambda \cdot B T}{c^{2}}\right) \ln \varepsilon}-273$

$L S T=$ ground surface temperature $\left({ }^{\circ} \mathrm{C}\right)$

$B T=$ brightness temperature value $(\mathrm{K})$

$\lambda=$ radiance emission wavelength $(\mathrm{m})$

$c=$ kecepatan cahaya $\left(3 \times 10^{8} \mathrm{~ms}^{-1}\right)$

$\varepsilon \quad=$ nilai emisivitas

This research uses remote sensing techniques in the form of alleged manifestations based on composite band data and geomorphological data. Several studies that have been conducted state that there is a relationship between the distribution of existing thermal anomalies and subsurface structures in geothermal areas $[19,20]$. Therefore, it is very important to carry out further research on the subsurface structure of the area to strengthen the allegations of identified geothermal manifestations. 
One of the geophysical methods that can be used to determine subsurface structures is the gravity method. The gravity method is a method of investigating the subsurface of the earth which is based on Newton's law [21]. The basic principle of the gravity method is to measure the difference in the value of the gravitational field caused by an uneven rock mass. The difference in gravity values can be used to estimate the geometry of subsurface structures globally including their density and depth [22]. Based on the gravitational force expressed in Newton's Law of attraction between two masses of particles $\mathrm{m} 1$ and $\mathrm{m} 2$, it is directly proportional to the product of their masses and inversely proportional to the square of the distance [21]. The following is an equation of Newton's law that states the equation:

$$
\begin{array}{ll}
F(r)= & -G \frac{m_{1} m_{2}}{r^{2}} \\
F(r) & =\text { gravity }(\mathrm{N}) \\
m_{1}, m_{2} & =\text { mass }(\mathrm{kg}) \\
r \quad & =\text { distance }(\mathrm{m}) \\
G \quad & =\text { gravity constant }\left(6.6732 \times 10^{-11} \mathrm{Nm}^{2} / \mathrm{kg}^{2}\right)
\end{array}
$$

The following is Figure 1 of the attractive force between 2 particles on a 2-dimensional plane:

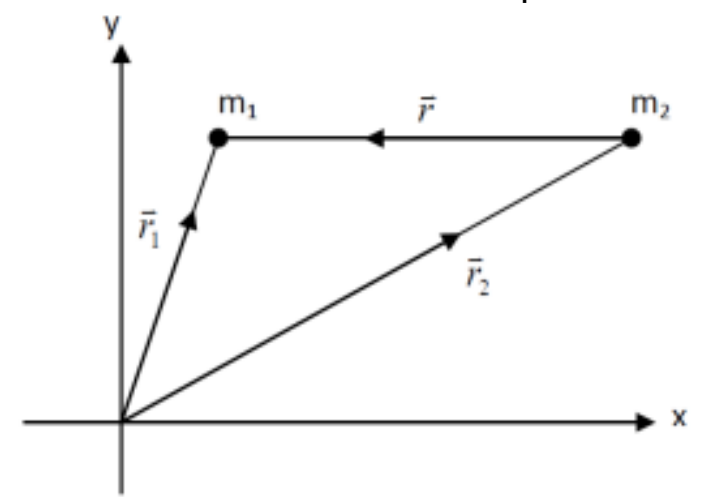

Figure 1. The gravitational force of 2 particles on a 2-dimensional plane [21]

The method of gravity is also based on Newton's second law of the relationship between force and acceleration. Newton's second law reads "The acceleration of an object is directly proportional to the net force acting on it and inversely proportional to its mass [21]. Mathematically Newton's second law can be expressed in the following equation:

$$
\begin{aligned}
& F=m_{2} \cdot g \\
& g=\frac{F}{m_{2}}
\end{aligned}
$$

So that equations (2) and (4) can be combined into a gravitational force, which is expressed as follows:

$g=\frac{F}{m_{2}}=G \frac{M_{1} \cdot m_{2}}{m_{2} \times r^{2}}=G \frac{M_{1}}{r^{2}}$

$g \quad=$ acceleration of the earth's gravitational force $\left(\mathrm{m} / \mathrm{s}^{2}\right)$

$F \quad=$ gravity $(\mathrm{N})$ 
$M_{1}=\operatorname{mass}(\mathrm{kg})$

$m_{2}=$ obect mass $(\mathrm{kg})$

$G \quad=$ gravitational constant $\left(6.6732 \times 10^{-11} \mathrm{Nm}^{2} / \mathrm{kg}^{2}\right)$

$r=$ distance between two objects $(\mathrm{m})$

The gravity data used in this study is GGMplus gravity data. Global Gravity Model plus (GGMplus) is satellite gravity data which is a combination of the GRACE, GOCE, EGM 2008 satellites, and high-resolution topographic information from the SRTM topography, which is approximately $200 \mathrm{~m}$ resolution. GGMplus gravity data provides a grid of data on gravitational acceleration, gravity disturbance, quasigeoid undulation, and north-south and west-east vertical deflections. The GGMplus gravity data used in this study is gravity disturbance data. Gravity disturbance data is satellite gravity data which is equivalent to gravity data that has been corrected in free air. The gravity disturbance data needs to be corrected to eliminate the values that affect the gravity value. The corrections include topographic corrections consisting of bouguer corrections and terrain corrections.

\section{Materials and Methods}

This research begins with a topic. The topic of this research is the utilization of Landsat 8 satellite imagery data and GGMplus satellite gravity data which are used as the first step in geothermal research at the lyang-Argopuro volcano complex. The type of data used in this study is secondary quantitative data in the form of Landsat 8 satellite image data downloaded from the website https://earthexplorer.usgs.gov/, gravity data from GGMplus downloaded from the website http://ddfe.curtin.edu.au/gravitymodels/GGMplus/data/ and the SRTM DEM data downloaded from the website http://srtm.csi.cgiar.org/srtmdata. The research area is the Mount lyang-Argopuro complex with the research coordinates of $7.895-8.045^{\circ}$ South Latitude and 113.511-113.705 East Longitude. The data obtained were then corrected based on each method. 


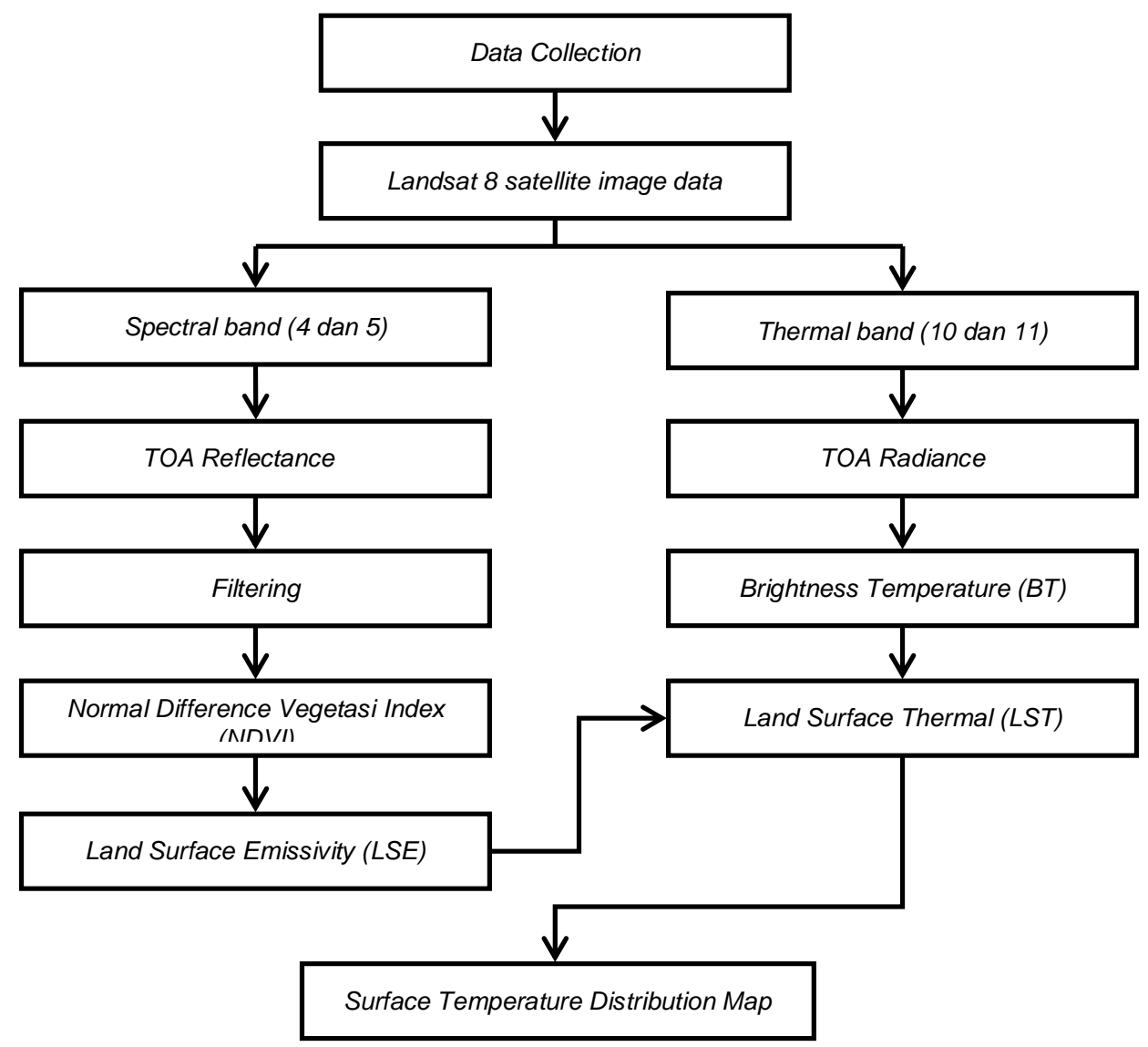

Figure 2. Stage of remote sensing methods

The data of Landsat 8 satellite imagery is a radiometric correction to eliminate the influence of the atmosphere during image recording. Radiometric correction or Top of Atmosphere (TOA) consists of two kinds of corrections, namely the TOA Reflectance correction (reflectance bands (4 and 5)) and TOA Radiance correction (radiance bands (10 and 11)). The result of the Reflectance TOA correction is the reflectance value and the result of the Radiance TOA correction is the radiance value.

The reflectance value obtained is then used for filtering to obtain the NDVI value. The NDVI value is obtained from equation 1. Furthermore, the NDVI value obtained is used to calculate the Vegetation Proportion (VP) value with the following equation.

$P V=\left(\frac{N D V I-N D V I_{\min }}{N D V I_{\max }-N D V I_{\min }}\right)^{2}$

The PV value is then used to determine the soil surface emissivity (LSE) value. The LSE value is used to reduce errors in calculating the soil surface temperature value. The emissivity value is obtained from the following equation. 
$\varepsilon=0.004 P V+0.96$

Furthermore, the radian value obtained from the TOA Radian correction is used to calculate the value of the soil surface temperature. The radian value is then converted to Brightness Temperature (BT) with equation 3. Furthermore, the BT value is used to calculate the value of the soil surface temperature with equation 4. After the soil surface temperature value is obtained, it will then be interpreted in the form of a map of the ground surface temperature. The ground surface temperature map will be used as a reference in determining geothermal manifestations, but the data is still not strong, so it will also be seen from the subsurface structure by looking at the local gravity value of the area.

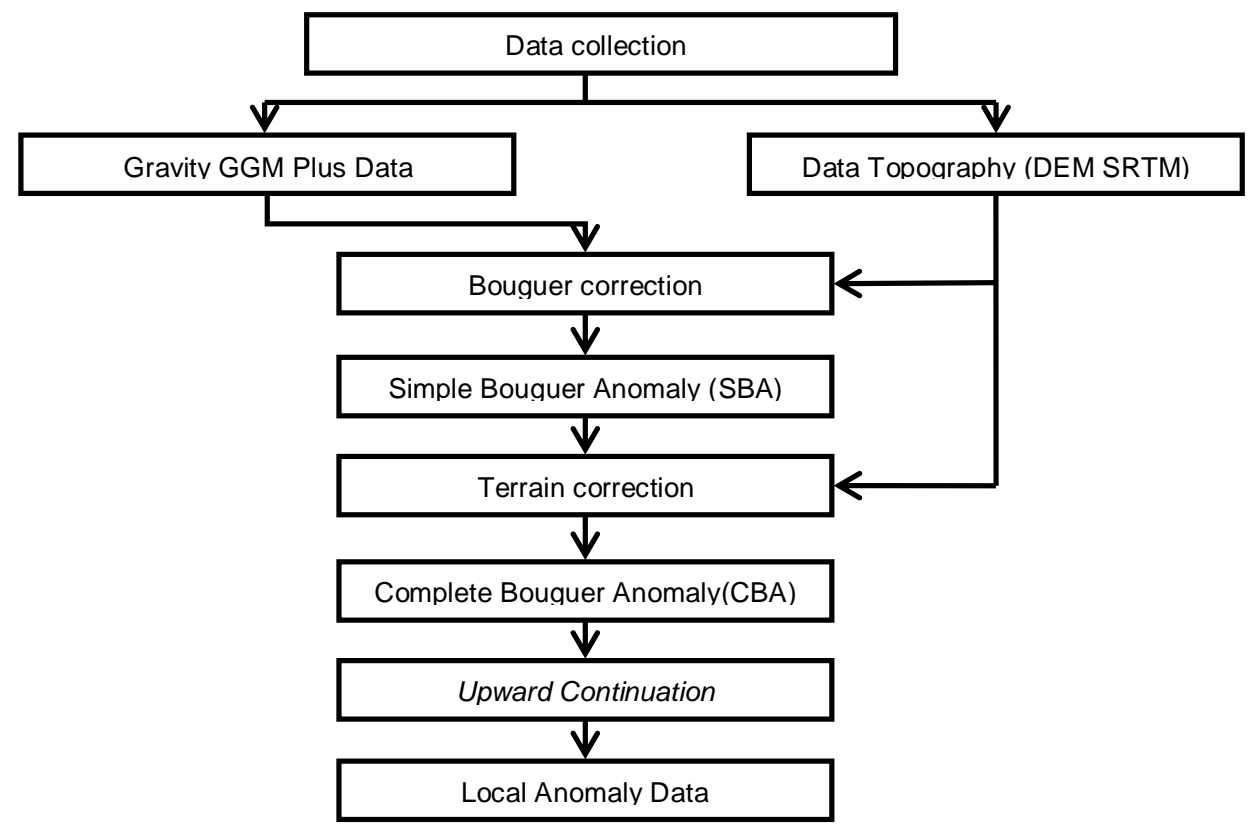

Figure 3. Stage of gravity method

GGMplus satellite gravity data (gravity disturbance) is equivalent to gravity data corrected in free air. So only need to do bouguer correction and terrain correction to get the Complete Bouguer Anomaly (CBA) value. Bouguer correction is carried out with the following equation [23].

$K_{B}=2 \pi G \rho h=0.0419 \times \rho \times H$

$K_{B}=$ bouguer correction

$G=$ gravity constant $=6.67 \times 10^{-11} \mathrm{~m}^{3} \mathrm{~kg}^{-1} \mathrm{~s}^{-2}$

$\rho=$ rock density $\left(2.67 \mathrm{gr} / \mathrm{cm}^{3}\right)$

$h=$ the height of the point is a measurement of gravity (from DEM SRTM data)

The results of the Bouguer correction are then used to find the value of the Simple Bouguer Anomaly (SBA) with the following equation.

$A B S=d g-K_{B}$ 
Where $d g$ is the gravity disturbance value and $K B$ is the bouguer correction value. The ABS value is still influenced by the topography at the measurement point. So it is necessary to do terrain correction to eliminate the influence of the topography. According to Reynolds (2011), the terrain correction is formulated by the following equation [24].

$K_{T}=\left(\frac{2 \pi \rho G}{n}\left[r_{2}-r_{1}+\sqrt{r_{1}^{2}+z^{2}}-\sqrt{r_{2}^{2}+z^{2}}\right]\right)$

$n=$ number of compartments in the research zone

$r_{2}=$ outer radius $(m)$

$r_{1}=$ inner radius $(m)$

$\mathrm{z} \quad=$ The difference between the average height of the compartment and the measuring point (m) (from DEM SRTM data)

Terrain correction is carried out with the help of Oasis Montaj 6.4.2 software. The results of the subsequent terrain correction are used to find the $A B L$ value with the following equation.

$A B L=A B S-K_{T}$

The $A B L$ value that has been obtained is then carried out with upward continuation filtering to separate local anomalies from regional anomalies in the area. The local anomaly data will be used to interpret the structure of the shallow surface area of the area.

\section{Results and Discussion}

Landsat 8 satellite imagery data that has been processed will produce vegetation density values and soil surface temperature values. The vegetation density values obtained are then classified into five classes, as shown in Table 2 . The results of the classification are then used as a vegetation density map as shown in Figure 4 below. 


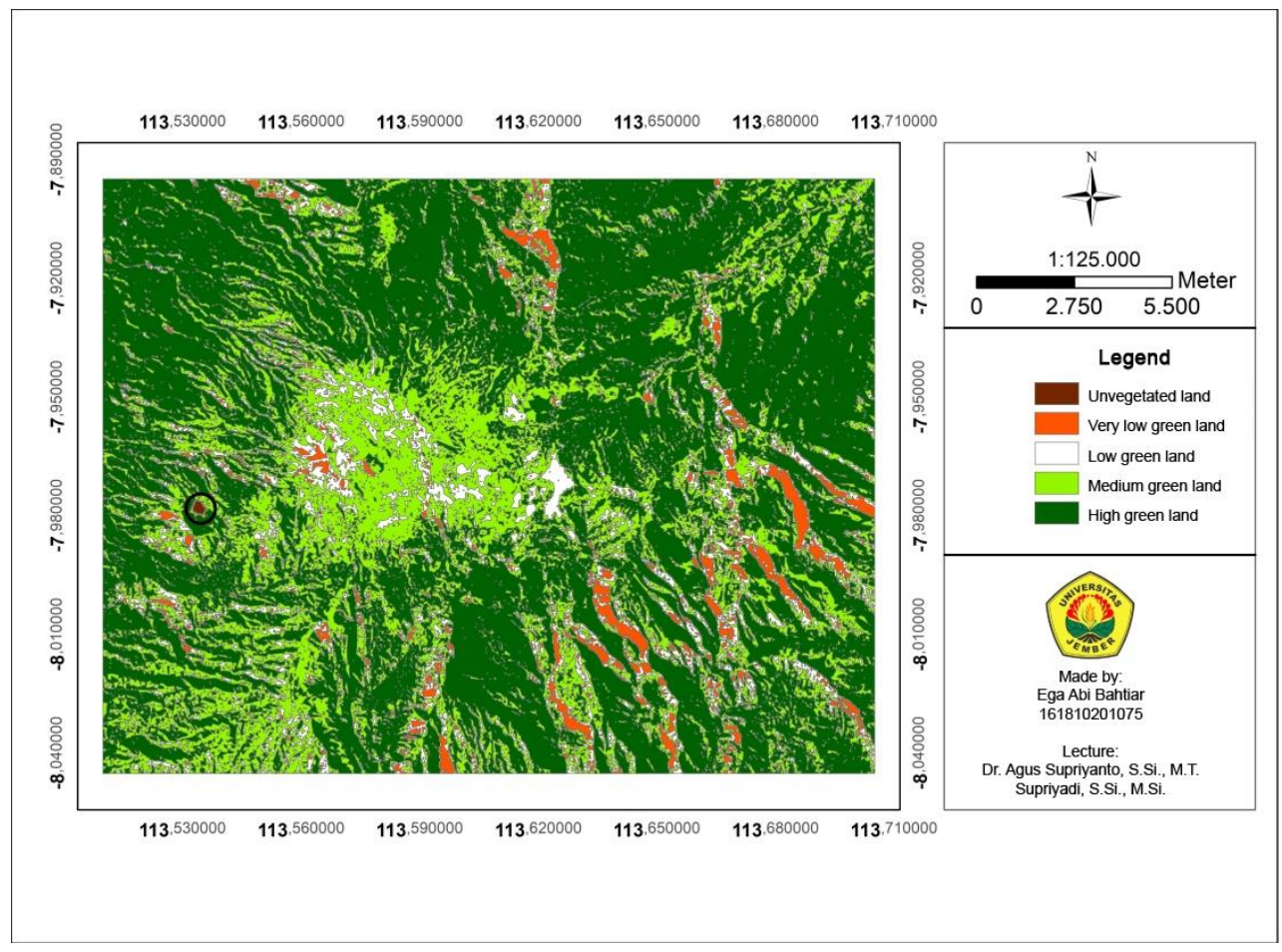

Figure 4. Vegetation density map of the lyang-Argopuro Volcano Complex

Figure 4 shows that the lyang-Argopuro Volcano Complex is dominated by a high green vegetation density class which is indicated by a dark green color. The middle part of the lyangArgopuro Volcano Complex has a low greenish vegetation density class. There is an unvegetated area marked by a black circle, the area is a living garden lake. Taman Hidup Lake is located at coordinates -7.978176 South Latitude, 113.532658 East Longitude, which is located in Krucil District, Probolinggo Regency. Based on the information on vegetation density in Figure 4, the location of the non-vegetated land area of Taman Hidup Lake has matches with the location coordinates with information from Google Earth.

The vegetation density value in Figure 4 will be used as a reference in mapping geothermal manifestations in the lyang-Argopuro Volcano Complex. According to Pietersz et. al. (2018) areas that have a high greenish vegetation density class generally have a lower ground surface temperature than the surrounding area [25]. However, this does not always apply to areas that have geothermal potential. The soil surface temperature in the geothermal potential area will be high even though the area has a high vegetation density class. The NDVI value obtained from processing band 4 and band 5 data in Figure 4 is then used as input to find the Vegetation Proportion (PV) value. The PV value obtained is used to determine the Estimated Land Surface (LSE) value. Furthermore, the LSE value serves to reduce errors in calculating the soil surface temperature value.

The soil surface temperature values in the lyang-Argopuro Volcano Complex range from $12{ }^{\circ} \mathrm{C}$ to $31{ }^{\circ} \mathrm{C}$, as shown in Figure 5 below. 


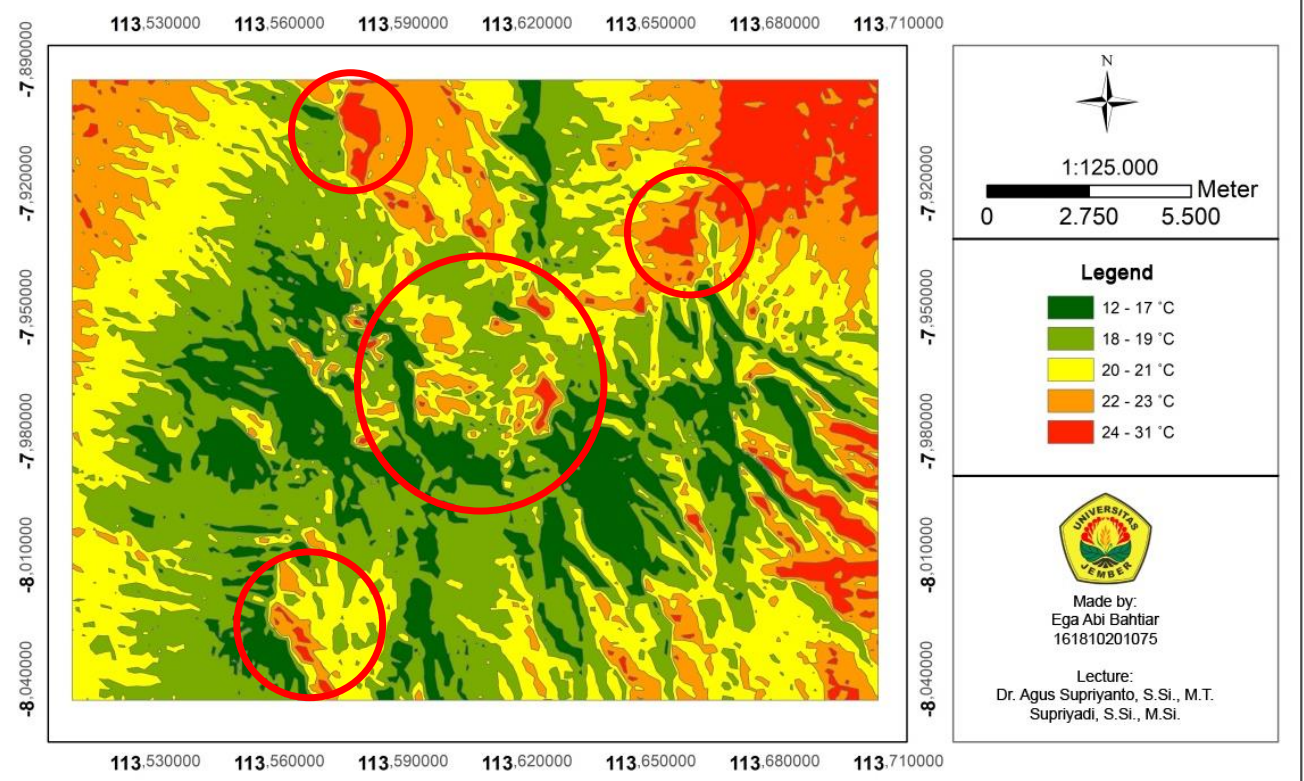

Figure 5. Map of ground surface temperature of lyang Argopuro Volcano Complex

Figure 5 shows that the lyang-Argopuro Volcano Complex has a high ground surface temperature ranging from $22-31{ }^{\circ} \mathrm{C}$ which is indicated by orange and red colors. Areas suspected to be geothermal manifestations are marked with red circles. Areas with high surface temperatures in the eastern part are not suspected as geothermal manifestations because based on Figure 4 these areas have low vegetation density values.

In conducting the initial estimation of geothermal manifestations in the lyang-Argopuro Volcano Complex using the value of the ground surface temperature, it will be compared with the reference ground surface temperature. According to research conducted by Purwantara (2015), the Mount lyang-Argopuro Complex has the highest ground surface temperature ranging from $22.1^{\circ} \mathrm{C}$ [26]. So that the ground surface temperature in Figure 5 with a range of values above $22.1^{\circ} \mathrm{C}$ can be assumed as a geothermal manifestation. Furthermore, the alleged manifestation of the soil surface temperature value will be strengthened by looking at the subsurface structure in the study area. The subsurface structure can be identified by looking at the value of local gravity in the study area.

The gravity disturbance data for GGMPlus is equivalent to gravity data corrected by free air, so to get the $A B L$ value, only bouguer correction and terrain correction are needed. ABL data is gravitational field data that is influenced by variations in rock density below the surface. This $\mathrm{ABL}$ data can interpret the subsurface structure of the study area.

The ABL contour map in the lyang-Argopuro Volcano Complex has a range of values between $32 \mathrm{mGal}$ to $90 \mathrm{mGal}$. As shown by Figure 6 below. 


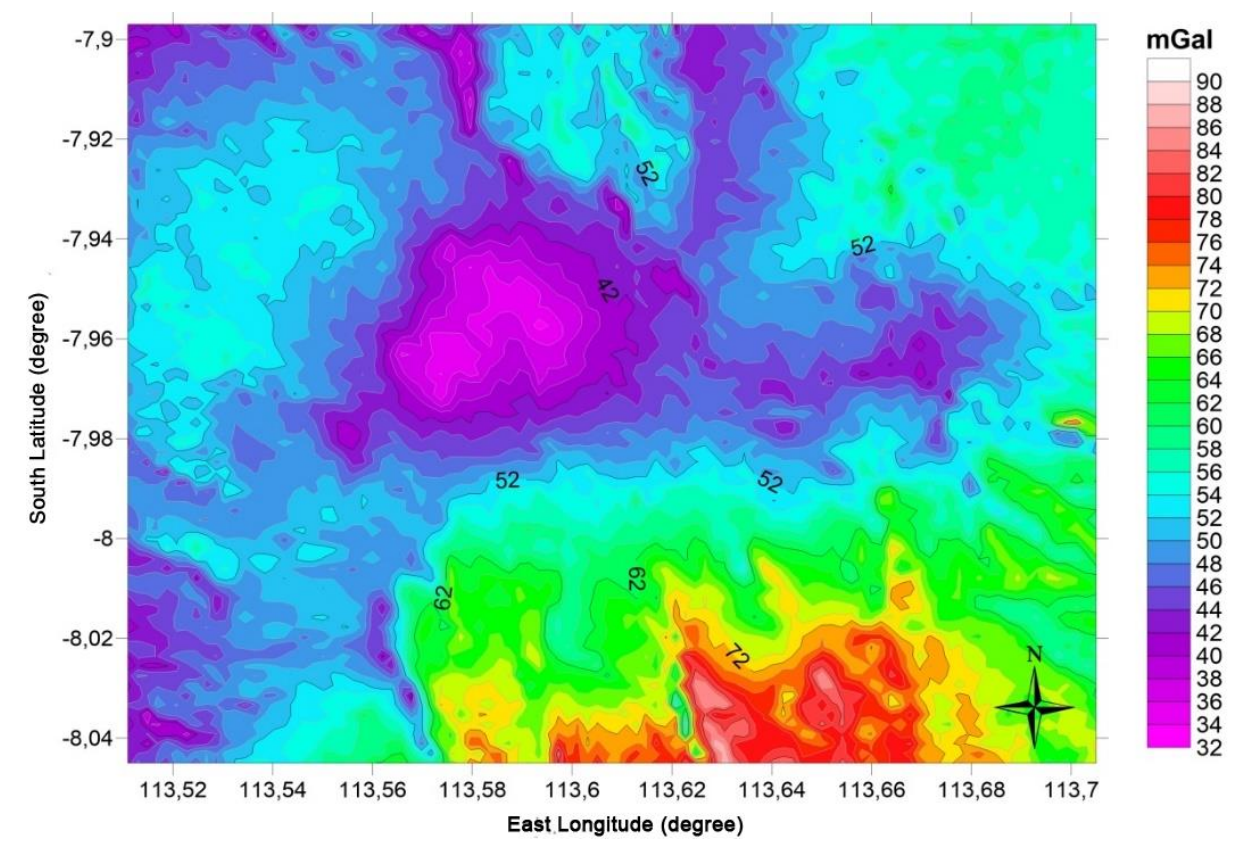

Figure 6. ABL contour map of the lyang-Argopuro Volcano Complex

The $A B L$ value in the center of the lyang-Argopuro Volcano Complex ranges from $33 \mathrm{mGal}$ to $42 \mathrm{mGal}$ which is indicated by the purple color. In the east, it is shown by a blue-purple color with a range of $20 \mathrm{mGal}$ to $52 \mathrm{mGal}$. The areas indicated by purple in the central and eastern parts are thought to be related to geothermal manifestations. In this study, the ABL value was used to determine the subsurface geological structure. Determination of the subsurface structure requires local anomaly data obtained from the separation of $A B L$ values into local anomalies and regional anomalies. Separation of these anomalies is done by using the upward continuation filtering method using the Magpick software.

Local anomaly data obtained can interpret the shallow subsurface structure in the study area. The best upward continuation filtering results at an upward value of $6000 \mathrm{~m}$. The following Figure 7 is a map of local anomalies in the lyang-Argopuro Volcano Complex which has a value range of $-20 \mathrm{mGal}$ to $28 \mathrm{mGal}$. 


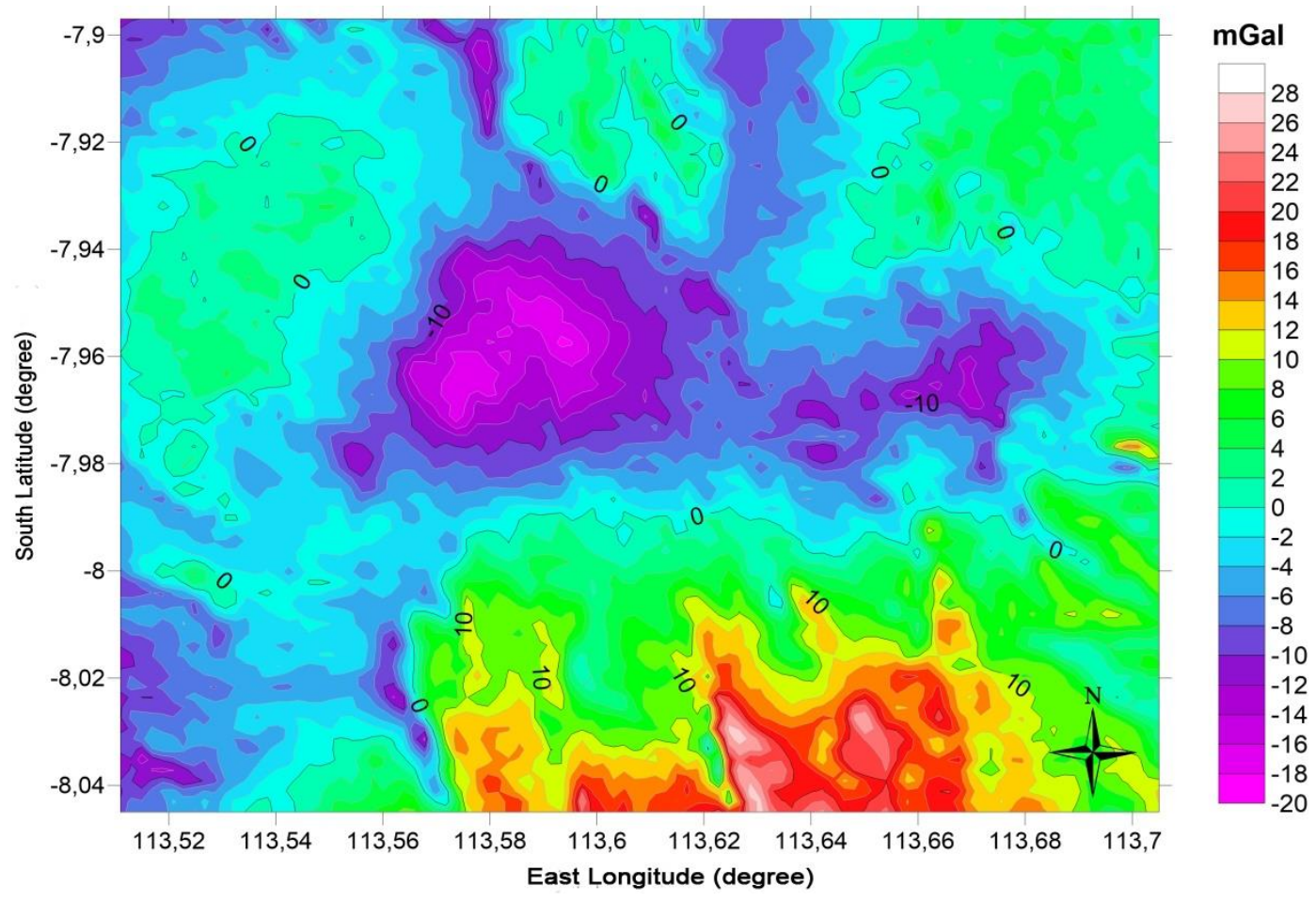

Figure 7. Local anomaly map as a result of continuation above $6000 \mathrm{~m}$

Low local anomalies are indicated by purple and blue colors which have a value of $0 \mathrm{mGal}$ to $20 \mathrm{mGal}$. The moderate anomaly has a value range of $0 \mathrm{mGal}$ to $14 \mathrm{mGal}$ which is indicated by green and yellow colors. While the high anomaly values are indicated by the orange and red colors which have a value range of $14 \mathrm{mGal}$ to $28 \mathrm{mGal}$. Local anomaly values which are suspected as geothermal manifestations are located in the central, eastern, southern, and northern parts indicated by purple and blue colors.

The low local anomaly which is suspected as a geothermal manifestation in Figure 7 will be searched for its relationship with the soil surface temperature in the study area. Figure 8 below is a map of overlay results from ground surface temperature data with local anomalies in the study area. 


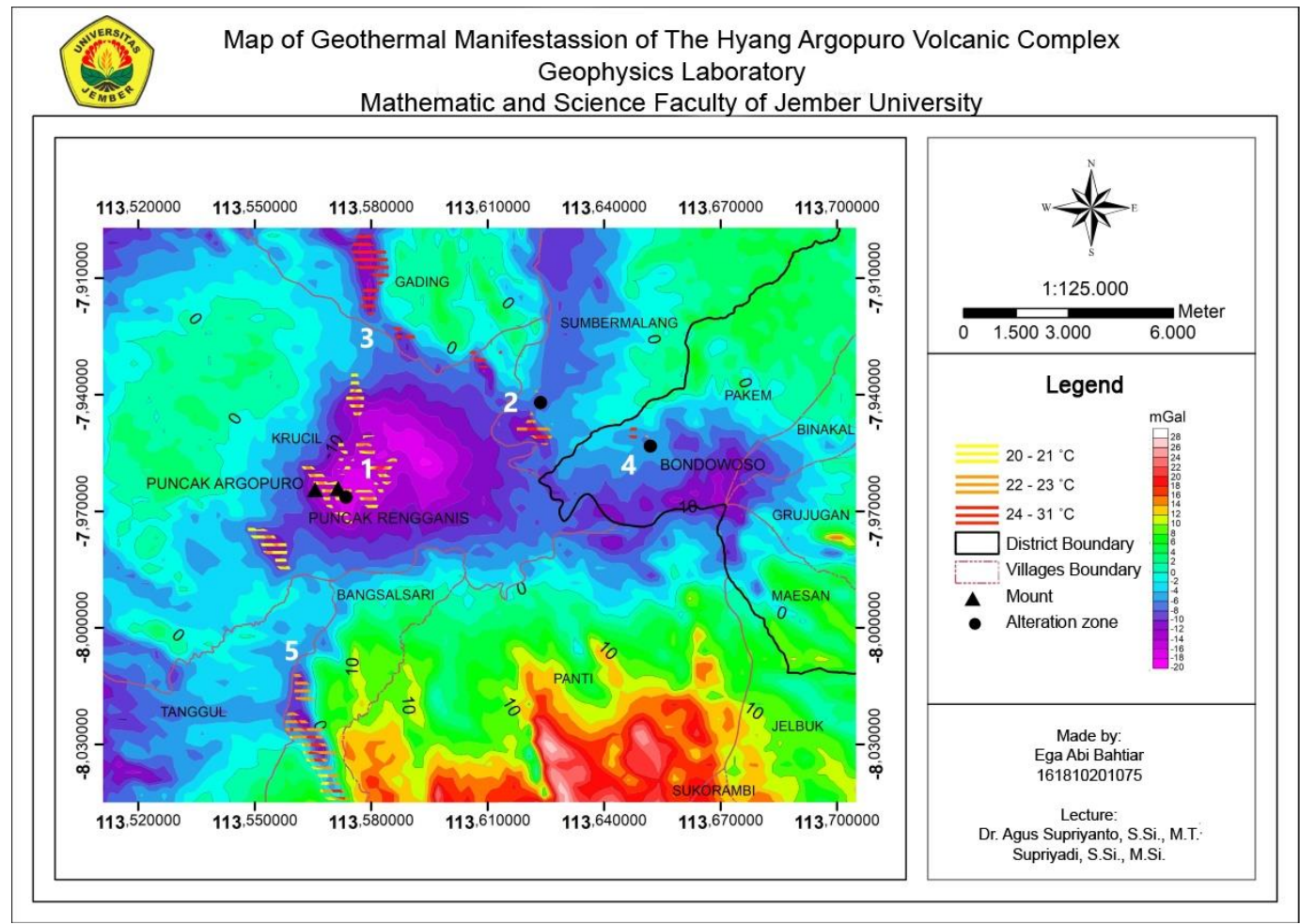

Figure 8. Overlay map of geothermal manifestations with administrative information of the research area

Figure 8 shows that there are five locations of geothermal manifestations in the lyang-Argopuro Volcano Complex. The location of these manifestations has a ground surface temperature of 20 $\mathrm{C}$ to $31{ }^{\circ} \mathrm{C}$ (yellow, orange, and red lines) with low gravity values ranging from $-20 \mathrm{mGal}$ to -6 mGal (purple color). The location of the first geothermal manifestation is located in the center with a temperature of $24-31{ }^{\circ} \mathrm{C}$ and gravity values ranging from $-20 \mathrm{mGal}$ to $-10 \mathrm{mGal}$. The location of the second manifestation is in the northeast with a temperature of $22-31{ }^{\circ} \mathrm{C}$ and gravity values ranging from $-12 \mathrm{mGal}$ to $-8 \mathrm{mGal}$. The location of the third manifestation is in the northern part with a temperature of $24-31{ }^{\circ} \mathrm{C}$ and a gravity value of $-16 \mathrm{mGal}$ to $-10 \mathrm{mGal}$. The location of the fourth manifestation is in the eastern part with a temperature of $24-31{ }^{\circ} \mathrm{C}$ and a gravity value of $-8 \mathrm{mGal}$ to $-6 \mathrm{mGal}$. The fifth manifestation location is in the southern part with a temperature of $22-31{ }^{\circ} \mathrm{C}$ and gravity values ranging from $-12 \mathrm{mGal}$ to $-6 \mathrm{mGal}$ rock structures with low density. This condition allows the outflow zone in the area. The outflow zone allows hot fluids in the earth to appear on the ground surface in the form of geothermal manifestations, one of which is a relatively high ground surface temperature from the surrounding area. The allegation of geothermal manifestations in the lyang-Argopuro Volcano Complex in Figure 8 is getting stronger. This occurs because the thermal anomaly obtained from processing Landsat 8 satellite imagery is related to the local anomaly obtained from processing the GGMplus gravity data as shown in Figure 8. 


\section{Conclusions}

This study has five points of geothermal manifestation locations in the lyang-Argopuro Volcano Complex which are located in the northern, central, southern and eastern parts. Manifestations in the northern, central, and northeastern parts have ground surface temperatures of $24-31{ }^{\circ} \mathrm{C}$. While manifestations in the central and eastern parts have a surface temperature of land 21-31 ${ }^{\circ} \mathrm{C}$. The location of the high ground surface temperature is associated with low gravity values with values ranging from $-20 \mathrm{mGal}$ to $-6 \mathrm{mGal}$. The location point is thought to be a geothermal manifestation in the lyang-Argopuro Volcano Complex. The location of the geothermal manifestation is located in the middle of the peaks of Mount Rengganis and Mount Argopuro. The northern part is in the Rabunan area, Probolinggo. The northeastern part of the Cikasur area, Situbondo. The eastern part is in the Bondowoso Regency area and the southern part is in Bangsalsari, Jember.

\section{References}

[1] Kasbani, 2014, Statistik Energi Terbarukan, Direktorat Jenderal Energi Baru Terbarukan, dan Konservasi Energi, Kementerian Energi dan Sumber Daya Mineral (KESDM).

[2] ESDM Jatim, 2012, Potensi Panas Bumi Jawa Timur 2012, http://esdm.jatimprov.go.id/esdm/attachments/article/37/Data\%20Eka-potensi\%20panas bumi\%20jatim\%202012.pdf.

[3] Direktorat Panas Bumi, 2017, Potensi Panas Bumi Indonesia, Jakarta: Direktorat Panas Bumi, Direkorat Jenderal Energi Baru, Terbarukan dan Konservasi Energi, Kementerian Energi dan Sumber Daya Mineral, Jilid 1

[4] S. Bronto, 2006, Fasies Gunung Api dan Aplikasinya, Indonesian Journal on Geoscience 1 (2): page 59-71.

[5] J. C. Wulandari, E. Z. Gaffar, S. Zulaikah and N. A. P, 2014, Penentuan Struktur Litologi Daerah Panas Bumi Probolinggo Menggunakan Metode Magnetotelurik (MT).

[6] M. Untung and G. Wiriosudarmo, 1975, The Structural Pattern of Java and Madura based on the Preliminary Interpretation of the Gravity, Technical Publication, Geophysical Series 2 (1).

[7] Saptadji, N. M, 2001, Teknik Panas Bumi, Bandung: Institut Teknologi Bandung

[8] Indarto, S., I. Setiawan, Sudarsono, A. F. Ismayanto and E. Z. Gaffar, 2012, Batuan Volkanik di sekitar Manifestasi Panas Bumi G, Rengganis Kompleks G, lyang-Argopuro, Probolinggo, Jawa Timur, Prosiding Geoteknologi LIPI.

[9] Thomas, L., K. R. W and C. Jonathan, 2015, Remote Sensing and Image Interpretation, John Wiley \& Sons

[10] W. Utama, A. S. Bahri and D. D. Warnana, 2012, Analisis Citra Landsat ETM+ untuk Kajian Awal Penentuan Daerah Potensi Panas Bumi di Gunung Lamongan, Tiris, Probolinggo, Jurnal Fisika dan Aplikasinya 8 (1): 120103, page 1-4.

[11] E. F. Littlefield and W. M. Calvin, 2014, Geothermal exploration using imaging spectrometer data over Fish Lake Valley, Nevada, Remote Sensing of Environment 140: page 509-518. 
[12] M. Blackett, 2014, Early analysis of Landsat-8 thermal infrared sensor imagery of volcanic activity, Remote sensing 6 (3): page 2282-2295.

[13] J. J. W. Rouse, R. H. Haas, J. A. Schell, and D. W. Deering, 1974, Paper A 20, Proceedings of Third Earth Resources Technology Satellite-1 Symposium: The Proceedings of a Symposium Held by Goddard Space Flight Center at Washington, DC on December 10-14, 1973: Prepared at Goddard Space Flight Center, 351, Scientific and Technical Information Office, National Aeronautics and Space 309

[14] Kustiyo, Y. M., and S. H. Pramono, 2005, Analisis Ketelitian Ketinggian Data DEM SRTM, MAPIN XIV, Pemanfaatan Efektif Penginderaan Jauh untuk Peningkatan Kesejahteraan Bangsa, Surabaya: Pertemuan IImiah Tahunan, page 14-15

[15] Departemen Kehutanan, 2012, Peraturan Menteri Kehutanan Republik Indonesia Tentang Cara Penyusunan Rencana Teknik Rehabilitasi Hutan dan Lahan Daerah Aliran Sungai (Rtk-Rhl DAS), Nomor : P.12/MENHUT-II/2012, Jakarta: Kemenhut

[16] Sutanto, 1994, Penginderaan Jauh Jilid II, Gajah Mada University Press, Yogyakarta.

[17] R. E. Munn, 2002, Encyclopedia of global environmental change, Citeseer

[18] T. R. Fariz, 2016, Pemanfaatan Citra Satelit dan Sistem Informasi Geografis untuk Pengembangan Ruang Terbuka Hijau Berdasarkan Estimasi Suhu Permukaan Daratan di Kota Pekalongan, Universitas Negeri Semarang.

[19] S. Bellani, A. Brogi, A. Lazzarotto, D. Liotta, and G. Ranalli, 2004, Heat flow, deep temperatures and extensional structures in the Larderello Geothermal Field (Italy): constraints on geothermal fluid flow, Journal of Volcanology Geothermal Research 132 (1), page 15-29.

[20] A. A. Aguilar, G. I. Montalvo, S. L. Blanco, and V. A. Gomez, 2017, Analysis of heterogeneous characteristics in a geothermal area with low permeability and high temperature, Geoscience Frontiers 8 (5): page 1039-1050.

[21] W. M. Telford, L. P. Geldart, and R. E. Sheriff, 1990, Applied geophysics, Cambridge university press.

[22] B. A. Sadjab, 2017, Identifikasi Struktur Bawah Permukaan Berdasarkan Analisis Anomali Gravitasi dan Didukung oleh Data Focal Mechanism Provinsi Nusa Tenggara Timur Lembar Kupang-Atambua, Universitas Gadjah Mada.

[23] M. Sarkowi, 2010, Identifikasi Struktur Daerah Panasbumi Ulubelu Berdasarkan Analisa Data SVD Anomali Bouguer, Sains MIPA 16 (2): page 111-118.

[24] J. M. Reynolds, 2011, An introduction to applied and environmental geophysics, John Wiley \& Sons.

[25] J. H. Pietersz, J. Matinahoru, and R. Loppies, 2018, Pendekatan Indeks Vegetasi Untuk Mengevaluasi Kenyamanan Termal Menggunakan Data Satelit Landsat-Tm Di Kota Ambon, Agrologia 4 (2).

[26] S. Purwantara, 2015, Studi temperatur udara terkini di wilayah di Jawa Tengah dan DIY, Geomedia: Majalah IImiah dan Informasi Kegeografian 13 (1). 